\title{
Samuel Beckett In Confinement. The Politics of Closed Space
}

James Little (2020).

London: Bloomsbury. 236 pp.

0

Juan Manuel Terenzi

UFSC/Brasil

Desde diciembre de 2019 estamos todos inmersos en un contexto de vida e interacción social distintos. Podría decirse que estamos rumbo a peor, según Beckett. La pandemia desatada por el virus COVID19 nos fue aislando dentro de límites cada vez más estrechos, no sólo en el ámbito físico, sino también en lo que se refiere al aspecto psicológico. Vivimos confinados en nuestros hogares para no ser contaminados o contaminar a los demás, y de esa forma vivimos cada vez más encerrados en nuestras mentes, aunque eso pueda ser discutido largamente.

Aún hoy, en el momento en que escribo esta reseña -en una isla en el sur de Brasil, en el mes de junio de 2021- no sabemos hacia dónde vamos, aunque las vacunas van llegando morosamente y una supuesta normalidad parece regresar. Dicho esto, el escenario en el cual nos encontramos parece ser muy conveniente y convincente para que Samuel Beckett lo ponderara literariamente, si estuviera vivo. Sin embargo, Beckett nos dio muestras de lo que es vivir confinado en muchas de sus obras. Los confinamientos beckettianos poseen una variedad enorme: hospitales psiquiátricos, cerebros, cárceles, tableros de ajedrez, entre otros. Por consiguiente, podemos decir que se trata del confinamiento del lenguaje, que James Little apunta como perteneciente a algo más allá de lo que Foucault había propuesto: "Las fuerzas que oprimen sus narradores van más allá de las formas del confinamiento, de tal modo que difieren del modelo coercitivo propuesto por Foucault, basado en un determinado conjunto de instituciones carcelarias" (p. 7).

Por lo tanto, en lo que refiere al contenido del libro de James Little, Samuel Beckett In Confinement. The Politics of Closed Space (2020), lo que leemos es justamente el agudo análisis y una profunda investigación de archivo de lo que serían los espacios cerrados a lo largo de la obra de Samuel Beckett. La mirada que pone Little sobre los espacios cerrados en la producción literaria de Beckett, adherida a la potencia que hay por detrás de ese material de archivo hacen que su lectura sea fundamental para poder entrar con más detenimiento no solo en los libros del escritor irlandés, sino también en nuestro tiempo pandémico. Un tiempo, que para asegurarnos la continuidad de la vida, transcurre entre confinamientos, aislamientos sociales, lockdowns y barbijos.

El libro de James Little está dividido en once momentos: una Introducción, nueve capítulos y la Conclusión. En la Introducción, Little nos demuestra cuáles serán sus herramientas teóricas, y los materiales de archivo investigados. El aporte bibliográfico es extenso, desde los estudios del profesor y crítico británico Peter Boxall, que en el artículo "Samuel Beckett: Towards a Political Reading" (2002) clamaba por una lectura política de la estética beckettiana, hasta el aporte que otros escritores y filósofos tuvieron sobre Beckett para que construyera sus espacios de confinamiento. Justamente sobre ese punto se detiene Little, cuando nos dice que "Antes de examinar los espacios carcelarios, que desempeñan un rol importantísimo en la narrativa beckettiana anterior a la segunda guerra, es necesario primero investigar las imágenes del confinamiento que Samuel Beckett ha rescatado de otros escritores y artistas mientras formaba su propia poética narrativa en los comienzos de su carrera literaria" (p. 11).

En lo que se refiere al contenido de los nueve capítulos: 1. Imágenes del confinamiento: Proust, Dream of Fair to Middling Women; 2. La Ética al Escribir el Confinamiento: "Dante and the Lobster", "Fingal", Murphy; 3. El Confinamiento "Errante": Watt; 4. "Deshaciendo" el Confinamiento: "The End", "The Expelled", Molloy, Malone Dies; 5. Arrepentimientos Políticos: Waiting for Godot, Endgame; 6. Aprendiendo a decir "Not I": The Unnamable; 7. Rehaciendo Not I en "No-A"; 8. "Los Límites de la Interpretación": Imagination Dead Imagine, All Strange Away; 9. La 
"Anética" al Escenar el Confinamiento: "Mongrel Mime", Catastrophe, se puede ver que el abanico de lectura de James Little es inmenso, y su arduo e incesante trabajo de archivo hace que la lectura de su libro sea imprescindible para todo investigador de la obra de Samuel Beckett.

Partiendo de la lectura de la Divina Comedia dantesca y sus círculos concéntricos, vamos conociendo y sumergiéndonos en ese riquísimo universo de lectura beckettiano, del cual derivó en parte sus espacios de confinamiento. Los más notables para cualquier lector de Beckett son el manicomio de Murphy, la habitación de Malone Muere, el espacio asfixiante de El Despoblador, o la boca de No Yo. Little los va deshilvanando uno a uno, entrando en la prosa, en el teatro, en las piezas de televisión, siempre con la mirada atenta para los cambios, tachaduras, garabatos, etc., que los archivos potencialmente demuestran. Su trabajo de profundo conocimiento y rigor en lo que se refiere a los estudios genéticos queda ampliamente demostrado, y las distintas capas que forman la escritura beckettiana nos van revelando importantes huellas que quedan ocultas cuando accedemos al libro impreso.

Por fin, en la Conclusión, leemos que en el año de 1984, Esperando a Godot fue escenificada (lamentablemente solo el primer acto, por razones de financiamiento) en una prisión de máxima seguridad en la ciudad de Kumla, Suecia. La proximidad, y por qué no decirlo, el carisma con el que Beckett se nutría de los encarcelados, no sólo por aquellos que se encuentran en las prisiones, sino también por los que están en los hospitales, en los manicomios, etc., hizo que él pudiera entrar en esos espacios con una mirada distinta y más humana. Los seres humanos atrapados forman una clave que ha resonado fuerte en la obra de Beckett. En última instancia, podríamos afirmar que se trata del lenguaje atrapado.

En seguida, cuando James Little nos invita al espacio reducido de la pieza de televisión Quad (1981) -que se presentó por primera vez por la Süddeutscher Rundfunk de Alemania, con el título de Quadrat I + II- a la que también se ha denominado como el ballet para cuatro actores, nos está invitando a algo que Beckett había propuesto en la carta redactada en alemán a Axel Kaun en el año de 1937, en la que afirmaba que era imperativo eliminar el lenguaje. Así, la tan anhelada Literatur des Unworts (Literatura de la despalabra) parece haber encontrado su lugar en Quad.

Las palabras finales del excelente libro de James Little convocan a un pensador muy presente para reflexionar sobre los espacios cerrados en Beckett: Gilles Deleuze. El concepto de "espacios cualesquiera" (espace quelconque) es pensado a partir de la pieza Quad: "Basándose en el concepto de "espacios cualesquiera”, el palco escénico de Quad parece ser un ejemplo de lo que Marc Augé ha llamado de "nolugar" (non-lieu) [...]" (p. 201).

Nosotros, mientras sigamos bajo la consigna de la pandemia, continuaremos tratando de volver a encontrar nuestros espacios cualesquiera. Samuel Beckett In Confinement. The Politics of Closed Space es un libro no solo para los investigadores de la literatura de Samuel Beckett, sino también un aporte precioso para tratar de entender lo que estamos viviendo hace ya más de un año. 